\title{
Bagaimana Literasi dan Perilaku Keuangan pada Generasi Milenial?
}

\author{
Mega Noerman Ningtyas ${ }^{\varpi}$, Novi Lailiyul Wafiroh \\ Fakultas Ekonomi, UIN Maulana Malik Ibrahim Malang \\ e-mail: meganoerman@uin-malang.ac.id
}

\begin{abstract}
The rise of illegal investment in Indonesia has made the OJK more vigorously conducting financial literacy education to the public. It is hoped that victims of illegal investment can be minimized in such a way that they can increase inclusion and public trust in financial services institutions and products in Indonesia. Research shows that individuals who have a high level of financial literacy will tend to do good financial planning such as: saving, making budgeting, paying debts on time and investing. This study aims to measure the level of financial literacy and how it affects financial behavior in millennial generations. Millennial generation here is the generation born between 1980-1994. This generation has unique characteristics where it is very concerned about social life and tends to be more consumptive than the previous generation. This is what makes it difficult for this generation to wisely manage finances. The results of this study indicate that financial literacy shows a significant positive effect on financial behavior. From this research it can be said that differences in knowledge will lead to differences in attitudes and behavior.
\end{abstract}

Keywords: financial literacy, financial behavior, millenial

\begin{abstract}
Abstrak
Maraknya investasi ilegal di Indonesia menjadikan Otoritas Jasa Keuangan (OJK) semakin gencar melakukan edukasi literasi keuangan ke masyarakat. Korban investasi liar diharapkan dapat diminimalisir sehingga dapat meningkatkan inklusi dan kepercayaan masyarakat terhadap lembaga dan produk jasa keuangan di Indonesia. Penelitian terdahulu menunjukkan bahwa individu yang memiliki tingkat literasi keuangan tinggi akan cenderung melakukan perencanaan keuangan yang baik seperti menabung, membuat penganggaran, membayar utang tepat waktu dan investasi. Penelitian ini bertujuan untuk mengukur tingkat literasi keuangan dan bagaimana pengaruhnya terhadap perilaku keuangan pada generasi milenial. Aspek literasi keuangan yang digunakan pada penelitian ini adalah literasi keuangan dasar, literasi keuangan lanjutan dan literasi keuangan syariah. Generasi milenial dalam konteks penelitian ini adalah generasi yang lahir antara tahun 1980-1994. Generasi ini memiliki karakteristik yang unik dimana sangat memperhatikan kehidupan sosial dan cenderung lebih konsumtif dibandingkan generasi sebelumnya. Hal inilah yang menjadikan generasi ini susah untuk bijak mengelola keuangan. Pada penelitian ini menggunakan metode Partial Least Square untuk pengujian
\end{abstract}


hipotesisnya. Hasil penelitian ini menyatakan bahwa literasi keuangan menunjukkan pengaruh positif signifikan terhadap perilaku keuangan.

Kata kunci: literasi keuangan, perilaku keuangan, milenial

\section{PENDAHULUAN}

Tercatat sebanyak 108 perusahaan investasi bodong selama tahun 2018 berhasil dibekukan oleh Otoritas Jasa Keuangan (OJK). Angka ini meningkat dibandingkan tahun lalu yaitu terdapat 80 investasi ilegal di luar fintech. Hal inilah yang menjadikan OJK sangat gencar melakukan edukasi literasi keuangan ke berbagai lapisan masyarakat. Korban investasi liar diharapkan dapat diminimalisir sehingga dapat meningkatkan inklusi dan kepercayaan masyarakat terhadap lembaga dan produk jasa keuangan di Indonesia.

Huston (2010) memberikan definisi literasi keuangan sebagai ukuran pemahaman individu terhadap pengelolaan keuangan pribadi berdasarkan penggunaan informasi yang dimiliki. Lusardi dan Mitchell (2011) memberikan batasan bahwa literasi keuangan hanya pengetahuan keuangan dan kemampuan untuk mengaplikasikannya. Sementara OJK mendefinisikan lebih kompleks yaitu literasi keuangan sebagai tingkat pengetahuan, keterampilan dan keyakinan masyarakat terkait lembaga keuangan serta produk dan jasanya, yang kemudian dituangkan dalam suatu ukuran indeks. Pengungkapan indeks literasi keuangan ini yang biasanya dilakukan tahunan menjadikan acuan OJK untuk terus melakukan edukasi pada masyarakat. Berdasarkan definisi tersebut, dapat disimpulkan bahwa literasi keuangan bukan sekadar pengetahuan keuangan saja namun sampai pada seseorang mampu, yakin dan percaya diri untuk membuat keputusan dan mengaplikasikan pengetahuannya pada kehidupan sehari-hari.

Berdasarkan survei OJK tahun 2016 bahwa tingkat literasi keuangan di Indonesia mengalami peningkatan dari tahun 2013 ke 2016 yaitu sebesar 21,8 persen ke 29,7 persen. Hal tersebut berarti di tahun 2016 dari 100 orang Indonesia yang menjadi responden survei hanya sebesar 30 orang saja yang termasuk pada kategori sangat terliterasi atau memahami serta memiliki keterampilan serta kemahiran dalam menggunakan produk dari jasa keuangan. Dapat dikatakan perbedaan pengetahuan mengarah pada perbedaan sikap. Literasi keuangan yang kurang ini kemudian bisa berdampak pada pengambilan keputusan yang salah dimana individu bisa sangat rentan menghadapi masalah penipuan bahkan dapat berdampak besar pada kesejahteraan finansial di masa yang akan datang.

Literasi keuangan merupakan ukuran pemahaman individu terhadap pengelolaan keuangan pribadi berdasarkan penggunaan informasi yang dia miliki (Huston, 2010). Berdasarkan DEFINIT-SEADI-OJK (2018), literasi keuangan pada dasarnya terbagi menjadi 2 jenis yaitu literasi keuangan dasar, yang menunjukkan kemampuan seseorang memahami konsep keuangan sederhana dan literasi keuangan lanjutan, yang menunjukkan kemampuan seseorang memahami konsep keuangan investasi khususnya di pasar modal. Pada penelitian ini, peneliti menambahkan aspek keuangan syariah yang diadaptasi dari Antara dkk. (2016). Hal ini disebabkan karena semakin banyaknya peminat bank syariah sehingga konsep keuangan islam ini juga perlu dikaji lebih dalam.

Bagaimana individu berperilaku dan mengambil keputusan dapat dijelaskan oleh theory of planned behavior. Proses pengambilan keputusan merupakan hasil dari serangkaian proses yang melibatkan sikap, norma dan pengendalian perilaku (Ajzen, 1991). Berdasarkan teori ini, perilaku 
seseorang akan dipengaruhi oleh jenis kelamin, usia, pengalaman, dan pengetahuan. Usia dan literasi keuangan memiliki korelasi positif, dimana semakin tua seseorang maka akan semakin berpengalaman dan akan semakin bijak dalam mengelola keuangannya (Laily, 2016). Begitu juga dengan perbedaan generasi terindikasi akan menimbulkan perbedaan perilaku.

Generasi Y atau generasi milenial adalah generasi yang lahir pada periode 1980-1994. Generasi ini memiliki karakteristik yang percaya diri, ekspresif, bebas, bersemangat terhadap hal baru dan terbuka pada tantangan dimana karakteristik tersebut sangat berbeda dengan generasi sebelumnya yaitu generasi X (1963-1977). Sebuah studi dari Boston Consulting Group (BCG) menyatakan bahwa generasi ini sangat memperhatikan kehidupan sosialnya. Jika dilihat dari segi tingkat konsumerisme, generasi ini cenderung lebih konsumtif karena mereka terbiasa mengikuti tren terbaru, suka berlibur untuk memenuhi keinginan swafoto di tempat yang indah atau lebih tepatnya mereka sebut 'instagrammable' (Ningtyas, 2019). Perkembangan teknologi digital memberikan dampak penuh pada gaya hidup generasi ini sehingga muncul istilah khusus yang menggambarkan fenomena baru yaitu the urban poor. Fenomena tersebut menggambarkan dimana seseorang ingin terlihat lebih baik di lingkungannya sehingga melakukan sesuatu di luar kemampuannya secara materi. Hal tersebut dilakukan untuk mendapatkan aktualisasi diri atau pengakuan dari lingkungannya (Jayaraman, www. buzzfeed.com).

Perilaku seseorang dilandaskan pada pengetahuan yang dimilikinya. Semakin ia memahami sesuatu maka ia akan bertindak sesuai dengan tingkat pengetahuan yang ia miliki. Beberapa penelitian terdahulu telah membuktikan adanya pengaruh antara literasi keuangan dengan perilaku keuangan. Individu yang terliterasi akan mampu melakukan dengan baik hal-hal seperti membuat penganggaran, menabung, mengontrol pengeluaran (Perry \& Morris, 2005); mengatur utang (Brown \& Graf, 2013; Lusardi \& Tufano, 2015); mengatur keuangan rumah tangga (Bellet, 2018); berpartisipasi dalam pasar modal (Bianchi, 2017; Christelis dkk., 2008; Jappelli \& Padula, 2013; Van Rooij dkk., 2011); membeli aset investasi yang berisiko tinggi (Bannier \& Neubert, 2016; Bianchi, 2017); merencanakan pensiun (Bucher-koenen dkk., 2011; Kumar dkk., 2019; Lusardi \& Mitchell, 2007, 2011); dan yang utama dan terpenting adalah berhasil mengakumulasi kekayaan yang dimilikinya (Bellet, 2018; Stango dkk., 2009).

Berdasarkan latar belakang yang dipaparkan sebelumnya, penelitian ini bertujuan untuk mengukur tingkat literasi keuangan dan bagaimana pengaruhnya terhadap perilaku keuangan pada generasi milenial. Penelitian ini merupakan penelitian lanjutan dimana peneliti menambahkan dimensi literasi keuangan syariah dari Antara dkk. (2016) untuk lebih memahami secara komprehensif terkait pengetahuan keuangan yang dimiliki oleh generasi milenial.

\section{METODE PENELITIAN}

Penelitian ini menggunakan metode survei untuk mengumpulkan data yaitu dengan cara menyebarkan angket atau kuesioner kepada responden penelitian yang merupakan generasi milenial. Generasi milenial adalah generasi yang lahir antara tahun 1980-1994. Kuesioner disebarkan secara daring yaitu melalui google form yang disebarluaskan melalui media sosial agar lebih luas menjangkau responden. Data diolah dengan analisis PLS menggunakan SmartPLS 3. Instrumen penelitian yang digunakan perlu juga diuji validitas dan reliabilitas sebelumnya untuk mendapatkan model yang fit. Untuk pengujian validitas, indikatorindikator yang memiliki nilai loading factor di bawah 0,5 akan dihilangkan dari model. 
Selanjutnya yaitu jika nilai cronbach alpha di atas 0,6 maka dapat dikatakan konstruk tersebut adalah reliabel. Jika konstruk telah valid dan reliabel kemudian dilanjutkan pada pengujian selanjutnya yaitu pengujian hipotesis. Hipotesis yang diajukan adalah apakah terdapat pengaruh yang signifikan antara literasi keuangan dan perilaku keuangan pada generasi milenial.

\section{HASIL DAN PEMBAHASAN}

Mengacu pada OJK (2016), terdapat empat klasifikasi literasi keuangan yaitu: 1) Sangat terliterasi-well literate (skor > $80 \%$ ). Artinya, mereka memiliki pemahaman dan keyakinan serta keterampilan dalam menggunakan produk dan jasa keuangan; 2) Cukup terliterasi-sufficient literate (skor $60-80 \%$ ). Artinya, mereka memiliki pemahaman dan keyakinan; 3) Kurang terliterasi-less literate (skor 30\%-60\%). Artinya mereka hanya memiliki pemahaman; 4) Tidak terliterasi-not literate (skor $>30 \%$ ). Artinya, mereka tidak memiliki pemahaman dan keyakinan serta keterampilan dalam menggunakan produk dan jasa keuangan.

Tabel 1. Persentase Literasi Keuangan dari Responden

\begin{tabular}{clc}
\hline \multicolumn{3}{l}{ Literasi Keuangan Dasar } \\
\hline Kode & Kategori Literasi Keuangan & $\%$ \\
\hline 1 & Tidak terliterasi & 1.2 \\
2 & Kurang terliterasi & 14.4 \\
3 & Cukup terliterasi & 31.7 \\
4 & Sangat terliterasi & 52.7 \\
\hline
\end{tabular}

\begin{tabular}{clc}
\hline \multicolumn{3}{l}{ Literasi Keuangan Lanjutan } \\
\hline Kode & Kategori Literasi Keuangan & $\%$ \\
\hline 1 & Tidak terliterasi & 18.5 \\
2 & Kurang terliterasi & 35.4 \\
3 & Cukup terliterasi & 27.6 \\
4 & Sangat terliterasi & 18.5 \\
\hline Literasi Keuangan Syariah & \\
\hline Kode & Kategori Literasi Keuangan & $\%$ \\
\hline 1 & Tidak terliterasi & 41.2 \\
2 & Kurang terliterasi & 37.0 \\
3 & Cukup terliterasi & 20.2 \\
4 & Sangat terliterasi & 1.6 \\
\hline
\end{tabular}

Sumber: Data Diolah (2019)

Tabel 1 menunjukkan persentase tingkat literasi keuangan dari semua responden. Literasi keuangan dasar menunjukkan kemampuan seseorang memahami konsep keuangan sederhana. Literasi keuangan lanjutan menunjukkan kemampuan seseorang memahami konsep keuangan yang lebih rumit yakni konsep investasi khususnya di pasar modal. Literasi keuangan syariah menunjukkan kemampuan seseorang memahami konsep-konsep keuangan Islam. Berdasarkan tabel di atas, mayoritas responden memiliki pemahaman, keyakinan dan keterampilan terkait dengan pengetahuan keuangan dasar sedangkan untuk pengetahuan keuangan lanjutan, mayoritas responden hanya sekadar memiliki pemahaman saja. Sebanyak 41 persen responden tidak memiliki pemahaman, keyakinan, dan keterampilan akan pengetahuan keuangan syariah. 
Bagaimana Literasi dan Perilaku Keuangan... (Mega Noerman Ningtyas, Novi Lailiyul Wafiroh)

Tabel 2. Rata-rata Tingkat Literasi Keuangan berdasarkan Demografi

\begin{tabular}{|c|c|c|c|}
\hline \multirow[t]{2}{*}{ Keterangan } & \multicolumn{3}{|c|}{ Kriteria Literasi Keuangan } \\
\hline & BFL & AFL & SFL \\
\hline \multicolumn{4}{|l|}{ Pendapatan per bulan } \\
\hline \multirow[t]{2}{*}{$<$ Rp1.000.000 } & 68.02821317 & 44.137931 & 39.148073 \\
\hline & sufficient literate & less literate & less literate \\
\hline \multirow[t]{2}{*}{$>$ Rp5.000.000 } & 82.39431818 & 59.875 & 39.7058824 \\
\hline & well literate & less literate & less literate \\
\hline \multirow[t]{2}{*}{ Rp1.000.000 - Rp2.500.000 } & 72.97805643 & 43.1034483 & 35.4969574 \\
\hline & sufficient literate & less literate & less literate \\
\hline \multirow[t]{2}{*}{ Rp2.600.000 - Rp5.000.000 } & 78.50560399 & 49.0410959 & 42.4657534 \\
\hline & sufficient literate & less literate & less literate \\
\hline \multicolumn{4}{|l|}{ Wilayah Tempat Tinggal } \\
\hline \multirow[t]{2}{*}{ Pedesaan } & 69.78609626 & 50.5882353 & 38.9273356 \\
\hline & sufficient literate & less literate & less literate \\
\hline \multirow[t]{2}{*}{ Perkotaan } & 78.42365402 & 50.631068 & 39.5488292 \\
\hline & sufficient literate & less literate & less literate \\
\hline \multicolumn{4}{|l|}{ Tempat Tinggal } \\
\hline \multirow[t]{2}{*}{ Jawa } & 77.45113103 & 50.6103286 & 39.5194698 \\
\hline & sufficient literate & less literate & less literate \\
\hline \multirow[t]{2}{*}{ Luar jawa } & 75.21885522 & 50.7407407 & 38.9978214 \\
\hline & sufficient literate & less literate & less literate \\
\hline \multicolumn{4}{|l|}{ Pekerjaan } \\
\hline \multirow[t]{2}{*}{ Dokter } & 68.18181818 & 60 & 20.5882353 \\
\hline & sufficient literate & sufficient literate & not literate \\
\hline \multirow[t]{2}{*}{ Dosen } & 81.81818182 & 54.5454545 & 43.8502674 \\
\hline & well literate & less literate & less literate \\
\hline \multirow[t]{2}{*}{ Freelance } & 88.63636364 & 50 & 36.7647059 \\
\hline & well literate & less literate & less literate \\
\hline \multirow[t]{2}{*}{ Guru } & 72.72727273 & 26.6666667 & 17.6470588 \\
\hline & sufficient literate & less literate & not literate \\
\hline \multirow[t]{2}{*}{ Ibu Rumah Tangga } & 74.16746411 & 52.6315789 & 34.9845201 \\
\hline & sufficient literate & less literate & less literate \\
\hline \multirow[t]{2}{*}{ Mahasiswa } & 71.81818182 & 48.25 & 41.7647059 \\
\hline & sufficient literate & less literate & less literate \\
\hline \multirow[t]{2}{*}{ Pegawai dan profesional } & 78.58468244 & 51.0958904 & 39.3634166 \\
\hline & sufficient literate & less literate & less literate \\
\hline \multirow[t]{2}{*}{ Pengusaha } & 77.57575758 & 50.6666667 & 44.3137255 \\
\hline & sufficient literate & less literate & less literate \\
\hline \multicolumn{4}{|l|}{ Pendidikan Terakhir } \\
\hline \multirow[t]{2}{*}{ SMA } & 68.58562368 & 47.2093023 & 36.6621067 \\
\hline & sufficient literate & less literate & less literate \\
\hline \multirow[t]{2}{*}{ S1 } & 78.82848485 & 49.5333333 & 37.6862745 \\
\hline & sufficient literate & less literate & less literate \\
\hline $\mathrm{S} 2$ & 79.88394584 & 57.2340426 & 47.6846058 \\
\hline & sufficient literate & less literate & less literate \\
\hline
\end{tabular}




\begin{tabular}{|c|c|c|c|}
\hline Status Pernikahan & & & \\
\hline \multirow[t]{2}{*}{ Belum menikah } & 76.72006652 & 50.304878 & 38.0200861 \\
\hline & sufficient literate & less literate & less literate \\
\hline \multirow[t]{2}{*}{ Menikah } & 78.08841843 & 50.6849315 & 42.7880741 \\
\hline & sufficient literate & less literate & less literate \\
\hline \multirow[t]{2}{*}{ Cerai } & 81.81818182 & 66.6666667 & 37.254902 \\
\hline & well literate & sufficient literate & less literate \\
\hline \multicolumn{4}{|l|}{ Agama } \\
\hline \multirow[t]{2}{*}{ Hindu } & 70.45454545 & 35 & 19.1176471 \\
\hline & sufficient literate & less literate & not literate \\
\hline \multirow[t]{2}{*}{ Islam } & 76.78489117 & 50.3286385 & 41.397404 \\
\hline & sufficient literate & less literate & less literate \\
\hline \multirow[t]{2}{*}{ Kristen Katolik } & 83.27272727 & 57 & 19.4117647 \\
\hline & well literate & less literate & not literate \\
\hline \multirow[t]{2}{*}{ Kristen Protestan } & 81.40559441 & 55.3846154 & 29.4117647 \\
\hline & well literate & less literate & not literate \\
\hline \multicolumn{4}{|l|}{ Usia } \\
\hline \multirow[t]{2}{*}{$24-28$} & 76.8486631 & 48.8823529 & 40.6574394 \\
\hline & sufficient literate & less literate & less literate \\
\hline \multirow[t]{2}{*}{$29-33$} & 77.66798419 & 53.6956522 & 38.2352941 \\
\hline & sufficient literate & less literate & less literate \\
\hline \multirow[t]{2}{*}{$34-38$} & 78.79166667 & 57.0833333 & 33.3333333 \\
\hline & sufficient literate & less literate & less literate \\
\hline \multicolumn{4}{|l|}{ Jenis Kelamin } \\
\hline \multirow[t]{2}{*}{ Laki-laki } & 77.73603505 & 54.8192771 & 41.8851878 \\
\hline & sufficient literate & less literate & less literate \\
\hline \multirow[t]{2}{*}{ Perempuan } & 75.44528083 & 48.4076433 & 38.1790933 \\
\hline & sufficient literate & less literate & less literate \\
\hline
\end{tabular}

Sumber: Data diolah (2019)

Keterangan:

BFL: Literasi keuangan dasar

AFL: Literasi keuangan lanjutan

SFL : Literasi keuangan syariah

Tabel 2 menunjukkan hasil deskripsi dari sampel penelitian berdasarkan demografi. Berdasarkan Theory of Planned Behavior, perilaku seseorang dilatarbelakangi beberapa faktor. Tabel 2 di atas menggambarkan berbagai latar belakang demografi mempengaruhi seberapa paham seorang individu akan pengetahuan keuangan, misalnya, berdasarkan jenis kelamin.

Laki-laki lebih memahami pengetahuan keuangan dibandingkan dengan wanita, baik dari literasi keuangan dasar, lanjutan maupun syariah. Hal ini sesuai dengan penelitian Klapper dkk. (2011) yang menyatakan bahwa wanita di 140 negara pada kondisi ekonomi bagaimanapun, baik negara berkembang maupun negara maju terbukti bahwa wanita memiliki nilai atau skor literasi lebih rendah. Penyebabnya adalah laki-laki lebih percaya diri akan pengetahuan dan kemampuannya dibandingkan perempuan (Baker dkk., 2019; Hung dkk., 2013). Laki-laki dan perempuan menghadapi kendala lingkungan yang berbeda, misalnya pekerjaan dan budaya 
dimana hal tersebut membatasi bagaimana keduanya belajar pengetahuan keuangan. Posisi perempuan yang menjalani dualitas peran antara ibu rumah tangga dan ibu pekerja juga memberikan dampak pada pengetahuan keuangan dan kepercayaan diri yang dimilikinya. Pada kategori usia pun demikian. Semakin tua seseorang maka ia memiliki pengetahuan keuangan lebih tinggi dibandingkan dengan kelompok yang lebih muda. Semakin tua, semakin berpengalaman dan akan semakin bijak dalam mengelola keuangannya (Laily, 2016).

Sebelum pengujian hipotesis maka perlu dilakukan uji validitas dan reliabilitas. Uji validitas dilakukan dengan cara menguji nilai factor loading dari indikator-indikator yang digunakan. Semua indikator yang memiliki nilai factor loading di bawah 0,5 akan dibuang dan kemudian model diuji kembali untuk mendapatkan model yang fit yaitu yang menunjukkan nilai factor loading $>0.5$. Selanjutnya, perlu dilakukan juga uji reliabilitas menggunakan cronbach alpha, jika nilanya $\geq 0.6$ maka indikator tersebut dapat dikatakan reliabel. Tabel 3 menunjukkan hasil pengujian validitas dan reliabilitas. Hasil pengujian menunjukkan bahwa semua indikator valid dan reliabel sehingga dapat dilanjutkan pada uji pengaruh.

Tabel 3. Hasil Uji Validitas dan Reliabilitas

\begin{tabular}{|c|c|c|c|}
\hline Dimensi & Indikator & $\begin{array}{c}\text { Loading } \\
\text { Factor }\end{array}$ & $\begin{array}{c}\text { Cronbach } \\
\text { Alpha }\end{array}$ \\
\hline \multirow{11}{*}{$\begin{array}{l}\text { Literasi Keuangan } \\
\text { Dasar }\end{array}$} & B1 & 2.012 & \multirow{11}{*}{0.502} \\
\hline & B2 & 0.402 & \\
\hline & B3 & 1.774 & \\
\hline & $\mathrm{B} 4$ & 4.997 & \\
\hline & B5 & 1.065 & \\
\hline & B6 & 0.383 & \\
\hline & B7 & 3.066 & \\
\hline & B8 & 1.423 & \\
\hline & B9 & 3.339 & \\
\hline & B10 & 3.012 & \\
\hline & B11 & 2.427 & \\
\hline
\end{tabular}

\begin{tabular}{|c|c|c|c|}
\hline \multirow{10}{*}{$\begin{array}{l}\text { Literasi Keuangan } \\
\text { Lanjutan }\end{array}$} & A1 & 2.807 & \multirow{10}{*}{0.69} \\
\hline & $\mathrm{A} 2$ & 2.6 & \\
\hline & A3 & 7.438 & \\
\hline & A4 & 8.042 & \\
\hline & A5 & 5.268 & \\
\hline & A6 & 13.09 & \\
\hline & A7 & 4.971 & \\
\hline & A8 & 2.765 & \\
\hline & A9 & 9.418 & \\
\hline & A10 & 5.618 & \\
\hline \multirow{17}{*}{$\begin{array}{l}\text { Literasi Keuangan } \\
\text { Syariah }\end{array}$} & S1 & 2.876 & \multirow{17}{*}{0.841} \\
\hline & S2 & 5.633 & \\
\hline & S3 & 3.022 & \\
\hline & S4 & 1.014 & \\
\hline & S5 & 2.56 & \\
\hline & S6 & 6.412 & \\
\hline & S7 & 5.571 & \\
\hline & S8 & 5.747 & \\
\hline & S9 & 5.61 & \\
\hline & S10 & 5.048 & \\
\hline & $\mathrm{S} 11$ & 4.633 & \\
\hline & $\mathrm{S} 12$ & 3.795 & \\
\hline & $\mathrm{S} 13$ & 4.299 & \\
\hline & $\mathrm{S} 14$ & 4.958 & \\
\hline & $\mathrm{S} 15$ & 0.789 & \\
\hline & S16 & 4.875 & \\
\hline & $\mathrm{S} 17$ & 3.961 & \\
\hline \multirow{10}{*}{ Perilaku Keuangan } & PK1 & 6.292 & \multirow{10}{*}{0.679} \\
\hline & PK2 & 5.614 & \\
\hline & PK3 & 1.634 & \\
\hline & PK4 & 5.559 & \\
\hline & PK5 & 1.373 & \\
\hline & PK6 & 1.557 & \\
\hline & PK7 & 9.817 & \\
\hline & PK8 & 9.304 & \\
\hline & PK9 & 6.329 & \\
\hline & PK10 & 6.82 & \\
\hline
\end{tabular}

Hipotesis yang diajukan pada penelitian ini adalah literasi keuangan berpengaruh terhadap perilaku keuangan. Hasil uji pengaruh menunjukkan bahwa baik literasi keuangan dasar, literasi keuangan lanjutan dan literasi keuangan syariah berpengaruh positif signifikan pada level lima persen terhadap perilaku keuangan. Artinya, semakin seseorang memahami aspek- 
aspek pengetahuan keuangan maka ia akan semakin baik dan bijak dalam mengelola keuangannya. Idealnya adalah demikian, namun seseorang yang paham keuangan, tidak serta merta akan berperilaku bijak dalam masalah keuangannya. Ada dimensi kepercayaan diri yang menyertai kemauan untuk berperilaku keuangan yang baik. Oleh karena itu, lembaga keuangan perlu sosialisasi lebih dalam agar kepercayaan diri dari masyarakat meningkat.

Tabel 4. Hasil Uji Pengaruh

\begin{tabular}{ll}
\hline Keterangan & P Values \\
\hline $\mathrm{BFL} \rightarrow \mathrm{FB}$ & $0.013^{* *}$ \\
\hline $\mathrm{AFL} \rightarrow \mathrm{FB}$ & $0.011^{* *}$ \\
\hline $\mathrm{SFL} \rightarrow \mathrm{FB}$ & $0.031^{* *}$ \\
\hline
\end{tabular}

Sumber: Data diolah (2019)

Keterangan: *.**, ${ }^{* * *}$ signifikan di level $10 \%, 5 \%$, dan $1 \%$.

Karakteristik generasi milenial yang cenderung menyukai pembayaran cashless dan memiliki daya beli yang kuat atau konsumtif sebenarnya merupakan blunder bagi generasi ini untuk tetap bijak dalam mengelola keuangannya. Di satu sisi ia harus memenuhi kebutuhan sehari-hari, di satu sisi ia juga perlu untuk mempertahankan eksistensi diri di lingkungan sosial dengan cara mengikuti tren terkini, menghabiskan waktu di cafe atau sekadar berlibur di tiap akhir pekan. Namun perkembangan teknologi menjadikan generasi ini sangat melek dengan informasi. Baik itu informasi dari media daring maupun dari media sosial. Informasi terkait perencanaan keuangan pun bisa mereka dapatkan secara cumacuma. Beberapa akun pada media sosial seperti Jouska dan Big Alpha ID secara rutin memberikan edukasi terkait pentingnya merencanakan dan menata keuangan dengan baik sejak dini seperti menabung, berinvestasi, membuat anggaran bahkan debt management. Bahkan lembaga resmi pemerintah seperti Indonesian Stock Exchange (IDX) dan Direktorat Jenderal Pengelolaan Pembiayaan dan Risiko (DJPPR) pun pada akun sosial medianya gencar memberikan edukasi perihal pentingnya berinvestasi dan dampaknya pada diri sendiri maupun ekonomi negara. Dengan begitu generasi milenial seharusnya dapat memanfaatkan informasi tersebut sebagai dasar pembuatan keputusan yang paling menguntungkan bagi kesejahteraan ekonominya di masa yang akan datang. Tak hanya itu, edukasi melalui sosial media juga bertujuan meningkatkan kepercayaan diri sehingga individu tidak hanya berhenti pada taraf 'tahu' saja namun 'mau' melakukan pengelolaan keuangan dengan baik.

\section{SIMPULAN DAN SARAN}

Hasil dari penelitian dapat disimpulkan bahwa literasi keuangan berpengaruh positif signifikan terhadap perilaku keuangan. Seseorang yang paham akan hal-hal keuangan seperti konsep bunga majemuk, nilai waktu uang bahkan konsep saham dan obligasi maka ia akan memiliki perilaku keuangan yang baik dan bijak. Dalam artian, orang tersebut melakukan penganggaran, menabung, membayar utang tepat waktu dan lain-lain. Saran penelitian selanjutnya, variabel-variabel dari dimensi sikap, norma, dan pengendalian perilaku dapat diteliti lebih dalam.

\section{REFERENSI}

Ajzen, I. (1991). The Theory of Planned Behavior. Organizational Behavior and Human Decision Processes, 50, 179-211.

Antara, P. M., Musa, R., \& Hassan, F. (2016). Bridging Islamic Financial Literacy and Halal Literacy: The Way Forward in Halal Ecosystem. Procedia Economics and Finance, 37(16), 196-202. https://doi.org/10.1016/ S2212-5671(16)30113-7 
Baker, H. K., Kumar, S., Goyal, N., \& Gaur, V. (2019). How financial literacy and demographic variables relate to behavioral biases. Managerial Finance, 45(1), 121-146. https://doi. org/10.1108/MF-01-2018-0003

Bannier, C. E., \& Neubert, M. (2016). Gender differences in financial risk taking: The role of financial literacy and risk tolerance. Economics Letters, 145, 130-135. https://doi.org/10.1016/j. econlet.2016.05.033

Bellet, E. (2018). Empowering Women Financially - The Why and the How. In The Fintech Handbook for Investors, Entrepreneurs and Finance Visionaries (Vol. 194, pp. 194-196).

Bianchi, M. (2017). " Financial Literacy and Portfolio Dynamics." Working Papers, (May).

Brown, M., \& Graf, R. (2013). Financial Literacy, Household Investment and Household Debt: Evidence from Switzerland. Working Papers on Finance, 13(1).

Bucher-koenen, T., Lusardi, A., Börschsupan, A., Fornero, E., Gasche, M., Haliassos, M., ... Lefter, A. (2011). Financial Literacy and Retirement Planning in Germany. Journal of Pen, 10(4), 565-584.

Christelis, D., \& et al. (2008). Cognitive Abilities and Portfolio Choice.

Hung, Angela; Yoong, Joanne; Brown, E. (2013). Women and financial literacy, (June).

Huston, S. J. (2010). Measuring Financial Literacy. The Journal of Consumer Affairs, 44(2), 296-316.

Jappelli, T., \& Padula, M. (2013). Investment in financial literacy and saving decisions. Journal of Banking and Finance, 37(8), 2779-
2792. https://doi.org/10.1016/j. jbankfin.2013.03.019

Klapper, L., Lusardi, A., \& Mitchell, O. S. (2011). Financial literacy around the world: An overview. Journal of Pension Economics and Finance, 10(4), 497-508. https://doi. org/10.1017/S1474747211000448

Kumar, S., Tomar, S., \& Verma, D. (2019). Women's financial planning for retirement Systematic literature review and future research agenda. International Journal of Bank Marketing, 37(1), 120-141. https:// doi.org/10.1108/IJBM-08-20170165

Laily, N. (2016). Pengaruh literasi keuangan terhadap perilaku mahasiswa dalam mengelola keuangan. Journal of Accounting and Business Education.

Lusardi, A., \& Mitchell, O. S. (2007). Baby Boomer retirement security: The roles of planning, financial literacy, and housing wealth. Journal of Monetary Economics, 54(1), 205-224. https://doi.org/10.1016/j. jmoneco.2006.12.001

Lusardi, A., \& Mitchell, O. S. (2011). Financial Literacy and Retirement Planning in US. National Bureau of Economic Research.

Lusardi, A., \& Tufano, P. (2015). Debt Literacy, Financial Experiences and Overindebtedness. Journal of Pension Economics \& Finance, 14(4), 332-368.

Ningtyas, M. N. (2019). Literasi Keuangan pada Generasi Milenial. Jurnal Ilmiah Bisnis Dan Ekonomi Asia, 13(1), 2027. https://doi.org/10.32812/jibeka. v13i1.111

Perry, V. G., \& Morris, M. D. (2005). Who Is in Control? The Role of SelfPerception, Knowledge, and Income 
in Explaining Consumer Financial Behavior. Journal of Consumer Affairs, 39(2), 299-313.

Stango, V., Zinman, J., Jel, D., Bernard, A., Benjamin, D., Choi, J., ... Staiger, D. (2009). Exponential Growth Bias and Household Finance. The Journal of Finance, 64(6).

Van Rooij, M., \& et al. (2011). Financial Literacy and Stock Market. Journal of Financial Economics, 101(2). 